Article

\title{
‘Aggregation-Induced Emission' Active Mono-Cyclometalated Iridium(III) Complex Mediated Efficient Vapor-Phase Detection of Dichloromethane
}

\author{
Pramod C. Raichure ${ }^{1}\left(\mathbb{D}\right.$, Vishal Kachwal ${ }^{1,2}$ and Inamur Rahaman Laskar ${ }^{1, *}$ \\ 1 Department of Chemistry, Birla Institute of Technology and Science, Pilani Campus, \\ Pilani 333031, Rajasthan, India; raichurepramod@gmail.com (P.C.R.); vishkachwal4@gmail.com (V.K.) \\ 2 Department of Engineering Science, University of Oxford, Oxford OX1 3PJ, UK \\ * Correspondence: ir_laskar@pilani.bits-pilani.ac.in
}

Citation: Raichure, P.C.; Kachwal, V.; Laskar, I.R. 'Aggregation-Induced Emission' Active Mono-

Cyclometalated Iridium(III) Complex Mediated Efficient Vapor-Phase Detection of Dichloromethane. Molecules 2022, 27, 202. https:/ / doi.org/10.3390/molecules27010202

Academic Editor: Youhong Tang

Received: 13 November 2021

Accepted: 23 December 2021

Published: 29 December 2021

Publisher's Note: MDPI stays neutral with regard to jurisdictional claims in published maps and institutional affiliations.

Copyright: (C) 2021 by the authors. Licensee MDPI, Basel, Switzerland. This article is an open access article distributed under the terms and conditions of the Creative Commons Attribution (CC BY) license (https:// creativecommons.org/licenses/by/ $4.0 /)$.

\begin{abstract}
Selective vapor-phase detection of dichloromethane (DCM) is a challenge, it being a wellknown hazardous volatile organic solvent in trace amounts. With this in mind, we have developed an 'Aggregation-induced Emission' (AIE) active mono-cyclometalated iridium(III)-based (M1) probe molecule, which detects DCM sensitively and selectively in vapor phase with a response time $<30 \mathrm{~s}$. It reveals a turn-on emission (non-emissive to intense yellow) on exposing DCM vapor directly to the solid M1. The recorded detection limit is $4.9 \mathrm{ppm}$ for DCM vapor with pristine M1. The mechanism of DCM detection was explored. Moreover, the detection of DCM vapor by M1 was extended with a low-cost filter paper as the substrate. The DCM is weakly bound with the probe and can be removed with a mild treatment, so, notably, the probe can be reused.
\end{abstract}

Keywords: aggregation-induced emission; dichloromethane; vapor phase; cost-effective

\section{Introduction}

The development of a selective and sensitive probe for hazardous volatile organic compounds (VOCs) is becoming a thrust area in the present day [1]. Most solvents are often used for various purposes to solve our daily problems. Dichloromethane (DCM) is commonly used as a solvent in laboratories and as a paint remover in industry; it is also used as an aerosol propellant, degreaser agent, room deodorant, herbicide, and insecticide [2,3]. Nowadays, it is not unknown that DCM inhalation causes severe health problems. A recent case of DCM injection injury in the finger shows the gravity of the toxicity of DCM [4]. The excessive usage and the high volatility of DCM result in significant contamination of water and air [5]. In general, the detection of DCM relies on gas chromatography [6,7], mass spectroscopy [8], or bioluminescent markers [9]. All these techniques require considerable time, high cost, and significant effort. However, reports on fluorescent-based sensing materials show sensitive detection of many organic solvents, including chloroform, DCM, methanol, acetone, tetrahydrofuran (THF), etc. Still, there is a concern over lack of selectivity, fast response, or the need for specific kinds of substrates [10-14]. Moreover, a more reliable, selective, and sensitive technique is needed in a real-time application.

Solid-state organic-based luminescent materials show a wide range of applications such as organic light-emitting diodes (OLED), solar cells, metal ion sensing, stimuliresponsive materials, bacterial imaging, etc. [15-19]. However, traditional organic luminophores exhibit emission quenching in the aggregated state, called 'Aggregation-caused Quenching' (ACQ), which limits their applications. Tang et al. first proposed a new concept called 'Aggregation-induced Emission' (AIE) in 2001 [20]. The luminescence of AIE active molecules in the solid phase is stronger than their solution or dispersed state. The AIE molecules emerged as a novel advanced material due to their excellent performance in various fields [21]. 
Recently, the research has been focused on fluorescence-based techniques for detecting volatile organic solvents, as the technique is more reliable and reduces the response time [22,23]. Liang et al. first explored quick and easy turn-on fluorescence sensing of DCM in a liquid state only, where Ln(III) complexes were synthesized through Schiff base-exchange reaction [24]. In 2020, Lang et al. published an article describing the host-guest chemistry by utilizing the metal-organic framework materials synthesized by $\mathrm{CuI}$ and tripyridyl phosphine for sensing chlorinated solvents $\left(\mathrm{CH}_{2} \mathrm{Cl}_{2}, \mathrm{CHCl}_{3}\right.$, and chlorobenzene) [25]. The technique is based on the host-guest chemistry, i.e., lock the guest solvent molecules in MOF, which induces luminescence enhancement. The MOF material is non-emissive in the absence of solvent molecules due to internal vibrations. It shows turn-on emission after restrictions of vibrations in the presence of solvent molecules. Here, the response time was less $(<1 \mathrm{~s})$, and also recyclability was high, but the materials were not selective to the DCM. It can also sense chloroform, carbon tetrachloride, and emissions observed at the same wavelength (580 $\mathrm{nm})$. Recently, Li et al. developed an ESIPT (excited-state intramolecular proton transfer) active $\mathrm{N}$-linked salicylaldehyde Schiff base organic compound to detect the $\mathrm{Cs}^{+}$and DCM with turn-off emission on the ligand to metal charge transfer (LMCT) process [26]. The detection limit in the case of DCM was $0.37 \%(v / v, 3700 \mathrm{ppm})$ in a solution state. All these studies reveal that a significant insufficiency exists in all the developed luminescent-based probes for detecting DCM.

Herein, we reported a new AIE active mono-cyclometalated Ir(III) complex (M1) for selective and sensitive detection of the DCM vapors. The synthesized M1 complex is non-emissive, but it shows light-on strong yellow emission upon interaction with DCM. The DCM vapors can be sensed on M1 impregnated filter paper as well as on thin film. The recorded detection limit for DCM vapor with $\mathrm{M} 1$ pristine is $4.9 \mathrm{ppm}$. To the best of our knowledge, it is the lowest limit of detection (LOD) obtained for a reusable, selective, and sensitive DCM detection with pristine probe till now [27].

\section{Results and Discussion}

The iridium(III)-based heavy-metal complex, M1 synthesized from ligand L1 (Scheme 1). The synthetic procedure for L1 and M1 is reported in the Supplementary Material. The synthesized compounds L1 and M1 are characterized by ${ }^{1} \mathrm{H},{ }^{13} \mathrm{C}$ NMR analysis (Figures S1-S4, tESI). In ${ }^{1} \mathrm{H}-\mathrm{NMR}(400 \mathrm{MHz}$, Chloroform- $d$ ), the observed peak at $\delta-16.82(\mathrm{~s}, 1 \mathrm{H})$ corresponds to iridium(III) hydride. In ${ }^{31} \mathrm{P}-\mathrm{NMR}(162 \mathrm{MHz}$, Chloroform- $d$ ), the observed singlet peak at $\delta 9.01$ relates the phosphorous in $\mathrm{PPh}_{3}$ ligand of M1 (Figure S5, +ESI). In HRMS spectrum, the observed mass corresponds to the calculated mass: $[\mathrm{M}-\mathrm{Cl}]^{+}: m / z=898.21$; found: $[\mathrm{M}-\mathrm{Cl}]^{+}: m / z=898.23$ (Figure S6, +ESI).<smiles>C=Cc1ccc(B(O)O)cc1</smiles><smiles>Brc1ccccn1</smiles>

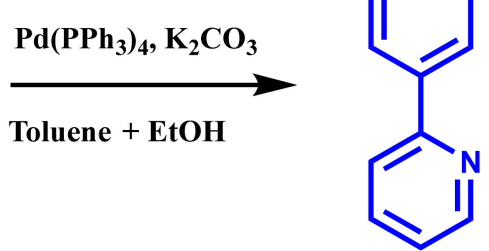

L1
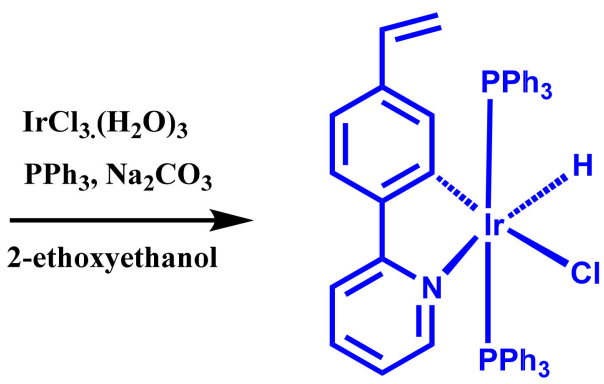

M1

Scheme 1. Synthesis of the ligand L1 and iridium(III) complex M1.

Here, the synthesized M1 is tested as an AIE-active compound. The AIE experiment for $\mathrm{M} 1$ is carried out by taking a mixture of THF and hexane solvents and preparing the mixture, as reported in supporting information (Figure S8, +ESI). The photoluminescence (PL) spectra of all the prepared solutions were recorded, and it indicates the PL intensity 
steadily increases with increasing hexane fractions. It can be explained by the AIE effect (Figure 1) [28]. The formation of aggregates with increasing concentration of hexane in THF was analyzed by dynamic light scattering (DLS) particle size distribution experiment. The observed particle size for $0 \%$ hexane percentage $\left(f_{h}\right)$ is $52.3 \mathrm{~nm}$ (with PDI 0.2 ) and for $90 \%$ hexane percentage $\left(f_{h}\right)$ is $170.5 \mathrm{~nm}$ (with PDI 1.1) (Figure S7, $\left.+E S I\right)$, which supports the formation of aggregates.

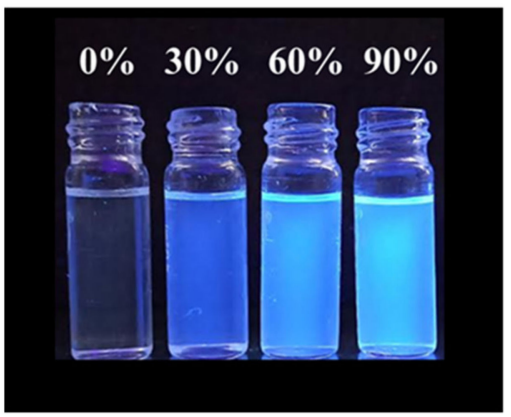

(a)

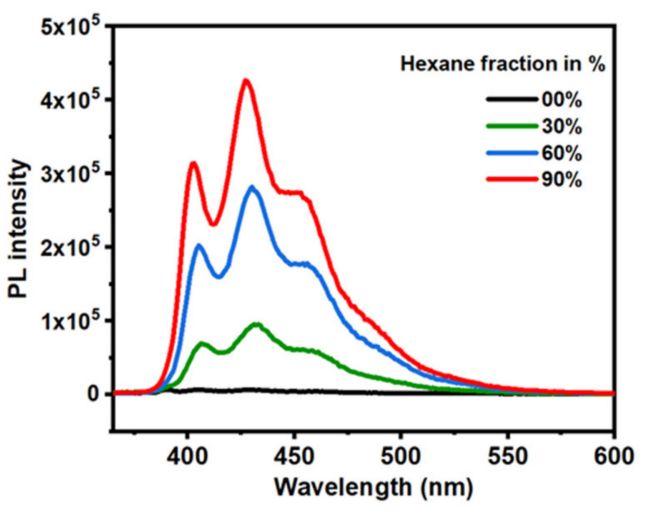

(b)

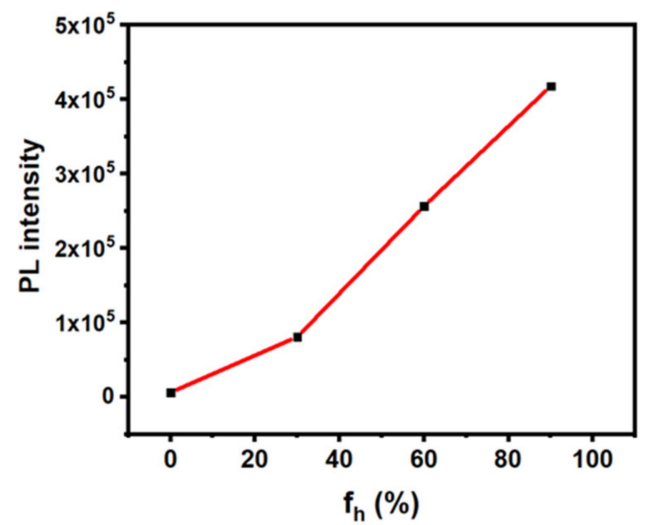

(c)

Figure 1. (a) Photograph of M1 in THF: hexane mixtures of various hexane fractions $\left(f_{h}\right)$ in percentage (\%) under UV lamp (365 nm); (b) PL spectra for the same under excitation of $360 \mathrm{~nm}$ wavelength; (c) Line plot for the changes in PL intensity for M1 with gradual increasing hexane percentage $\left(f_{h}\right)$ in THF: hexane mixture.

The reason behind the AIE activity has often been described as the restriction of intramolecular rotation (RIR) of the peripheral ring in the aggregated state, which reduces the non-radiative decay and increases the radiative pathway resulting in emission enhancement [28]. Here, the AIE effect is speculated due to the restricted intramolecular rotation (RIR) mechanism. To prove the RIR effect at the cause of AIE, a viscous solvent poly(ethylene)glycol (PEG) was chosen, and the emission spectra of the solutions prepared with gradual increasing concentration of PEG into THF (gradual variation of viscosity of the medium) were studied (Figure S8, +ESI). It was observed that PL intensity increases with the gradual addition of PEG in THF: PEG mixture supporting the RIR mechanism.

The DCM detection tested with the probe M1 in pristine form (in powdered and thin-film also). The thin film of M1 is made on a glass substrate by a drop-casting method. It was observed that non-emissive M1 shows turn-on yellow emission at $530 \mathrm{~nm}$ by putting a drop of DCM on powdered M1 and for thin-film upon $30 \mathrm{~s}$ exposure of DCM vapor generated by setting the temperature at $33^{\circ} \mathrm{C}$ (Figure 2). The probe M1 could also detect the DCM on impregnated filter paper with M1 (Figure 3).

To check the sensing selectivity of the M1 complex, it was screened with different solvents, which are generally used in industries and laboratories. For this experiment, the solution of M1 probe was prepared ( $1 \mathrm{mg}$ M1 in $1 \mathrm{~mL}$ toluene). Then, equal amount ( $20 \mu \mathrm{L})$ drop of this prepared probe solution was placed on each of 24 small strips of Whatman No 1 filter paper by the drop-casting technique. After which, the filter paper strips containing M1 were annealed under the oven for about one hour at $70{ }^{\circ} \mathrm{C}$. Various solvents were dropped on different annealed paper strips and observed emission, under a UV-visible lamp (Figure 4). The M1 shows turn-on yellow emission in the presence of DCM and its analogue dibromomethane (DBM) only, while not with other solvents (vide supra). This experiment clearly shows that the M1 selectively detects the DCM and DBM (Figure 4). 


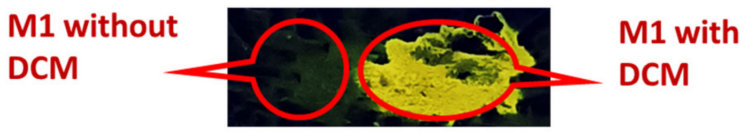

(a) Powdered form
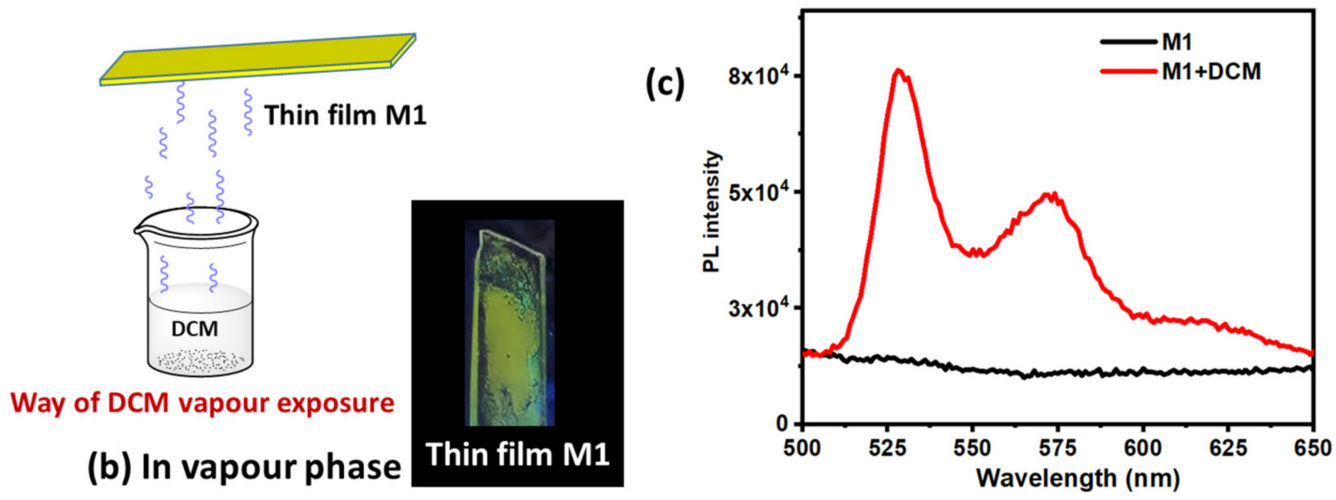

Figure 2. Images for DCM sensing: (a) in powdered form, (b) in the vapor phase with a representation of the way of exposing M1 thin film to DCM vapors (drawn) (left); actual image of emission after exposure to DCM vapor (right), (c) PL spectra for powdered M1 and M1 with DCM (wavelength: excitation $=360 \mathrm{~nm}$, emission $=530 \mathrm{~nm}$ ).

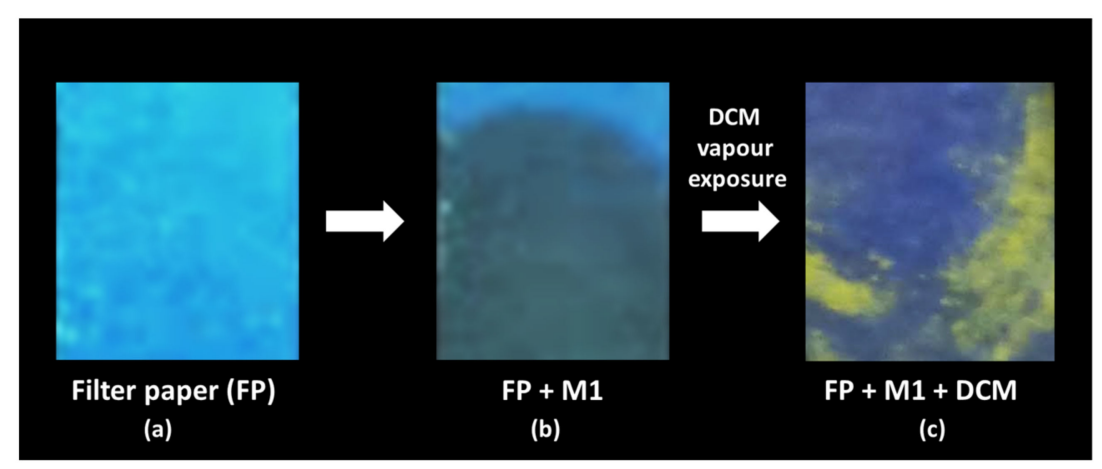

Figure 3. Images of filter paper (FP) under UV-visible lamp (365 nm): (a) filter paper (FP) only; (b) filter paper (impregnated with a solution of M1 in toluene) without DCM vapor; and (c) filter paper (impregnated with M1) in the presence of DCM vapors (turn on emission can be observed in the presence of DCM vapors).

The M1 probe showed similar emission spectra while testing with DCM and DBM separately $\left(\lambda_{\text {exi }}, 360 \mathrm{~nm}\right)$ (Figure S10, +ESI). DBM is a high boiling solvent $\left(97^{\circ} \mathrm{C}\right)$, rarely used in laboratories and industries compared to its analogue DCM. All the sensing studies were performed with DCM as focal attention. After screening with different solvents, the selectivity of the probe M1 towards DCM was tested successfully.

The controlled experiment was performed to check DCM detection in vapor phase by generating a saturated DCM vapor in a closed pack container at a constant temperature, $33{ }^{\circ} \mathrm{C}$ (Figure S11, +ESI). To eliminate all the possibilities for the leakage of the DCM vapor, the container with the outlet was tightly air-packed. The M1 was taken as a powdered form in the solid sample holder. The sample holder was exposed to the DCM vapor at the outlet. Emission spectra were recorded by irradiating the solid sample holder directly under $360 \mathrm{~nm}$ excitation (Figure 5). For each reading, the solvent was heated to $33^{\circ} \mathrm{C}$ for two minutes to generate the saturated vapors of DCM and M1 sample holder exposed to the DCM vapor for $30 \mathrm{~s}$. The saturated vapor pressure of DCM at $33{ }^{\circ} \mathrm{C}$ is $86 \mathrm{kPa}$ [29]. Thus, $86 \mathrm{kPa}$ vapor of DCM was exposed to probe M1 for each reading. The emission intensity gradually increased for each exposure of DCM vapor. A linear relationship can be 
observed between the emission intensity of M1 and DCM vapor concentration from 0 to $1204 \mathrm{kPa}$ (Figure 5). The obtained detection limit was 4.9 ppm $(0.000497 \mathrm{kPa})$ (Figure S12, tESI) in the vapor state, which is much less than the saturated vapor pressure of DCM at $33{ }^{\circ} \mathrm{C}(86 \mathrm{kPa})$. The LOD also crosses the setting inhalation limit (75 to $100 \mathrm{ppm}$ for an hour inhalation) [30].

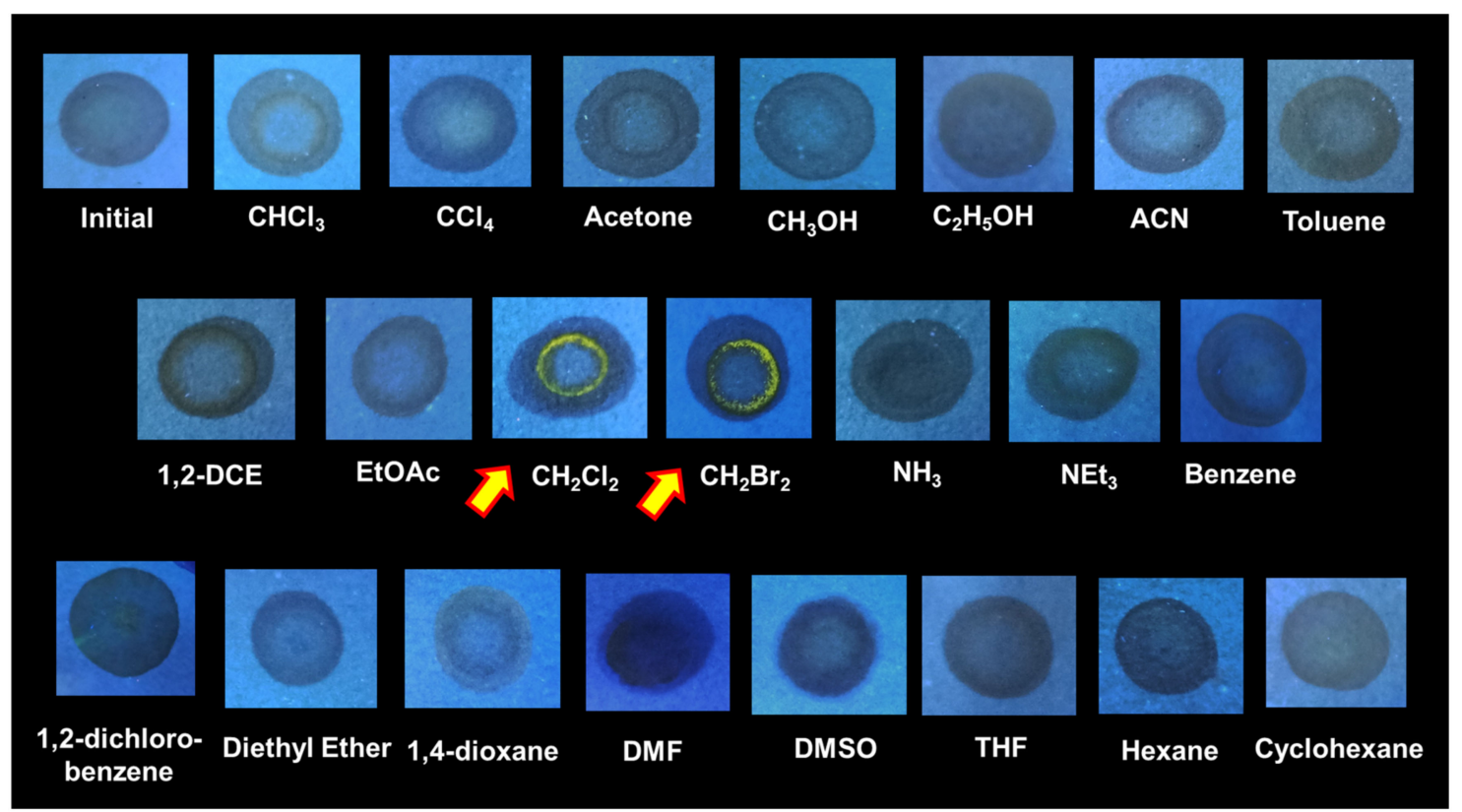

Figure 4. Photograph of selectivity test of $\mathrm{M} 1$ with the various solvents chloroform $\left(\mathrm{CHCl}_{3}\right)$, carbon tetrachloride $\left(\mathrm{CCl}_{4}\right)$, acetone, methanol $\left(\mathrm{CH}_{3} \mathrm{OH}\right)$, ethanol $\left(\mathrm{C}_{2} \mathrm{H}_{5} \mathrm{OH}\right)$, acetonitrile $(\mathrm{ACN})$, toluene, 1,2-dichloroethane (1,2-DCE), ethyl acetate (EtOAc), dichloromethane $\left(\mathrm{CH}_{2} \mathrm{Cl}_{2}\right)$, dibromomethane $\left(\mathrm{CH}_{2} \mathrm{Br}_{2}\right)$, ammonia $\left(\mathrm{NH}_{3}\right)$, triethylamine $\left(\mathrm{NEt}_{3}\right)$, benzene, 1,2-dichlorobenzene, diethyl ether, 1,4dioxane, N, N-Dimethylformamide (DMF), dimethyl sulfoxide (DMSO), tetrahydrofuran (THF), hexane, and cyclohexane on Whatman No 1 filter paper under UV lamp (365 nm) (The arrows indicate the turn-on emission response with dichloromethane and dibromomethane only).

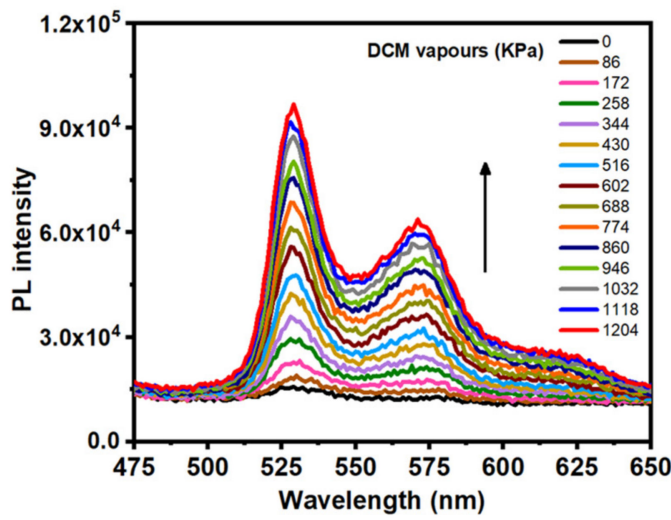

(a)

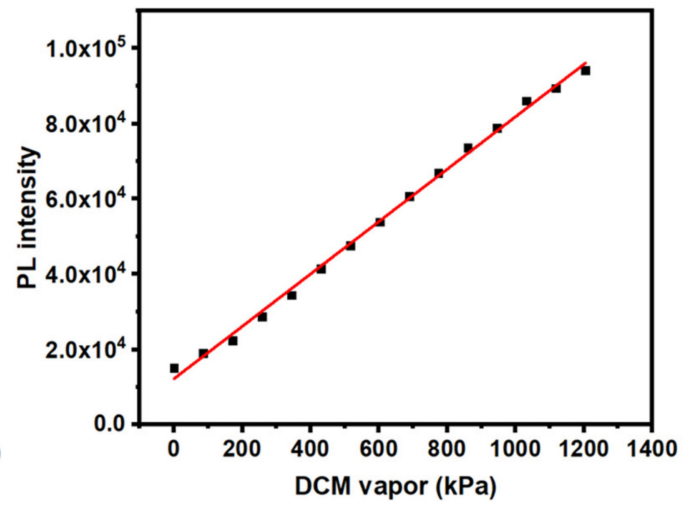

(b)

Figure 5. (a) PL spectra of M1 (powdered in solid sample holder) with gradually increasing DCM vapor concentration excited at $360 \mathrm{~nm}$, (b) Plot between PL intensity of M1 vs. DCM vapor concentration (Pearson's r value $=0.99$ )

The probe M1 can be recycled. The powdered form of M1 treated with DCM vapor was kept in the open air. It was observed that the emission intensity of the probe decreased gradually and returned to pristine form on keeping the powder at $25^{\circ} \mathrm{C}$ for $40 \mathrm{~min}$. The 
rate of desorption of DCM is accelerated by heating the sample at $80^{\circ} \mathrm{C}$ continuously for $30 \mathrm{~s}$.

The experiment was repeated several times to check the stability and reusability of the probe in the vapor phase (Figure 6). Even in the seventh cycle, the emission intensity almost remains the same. Hence, the same probe can be reused again for further sensing applications.

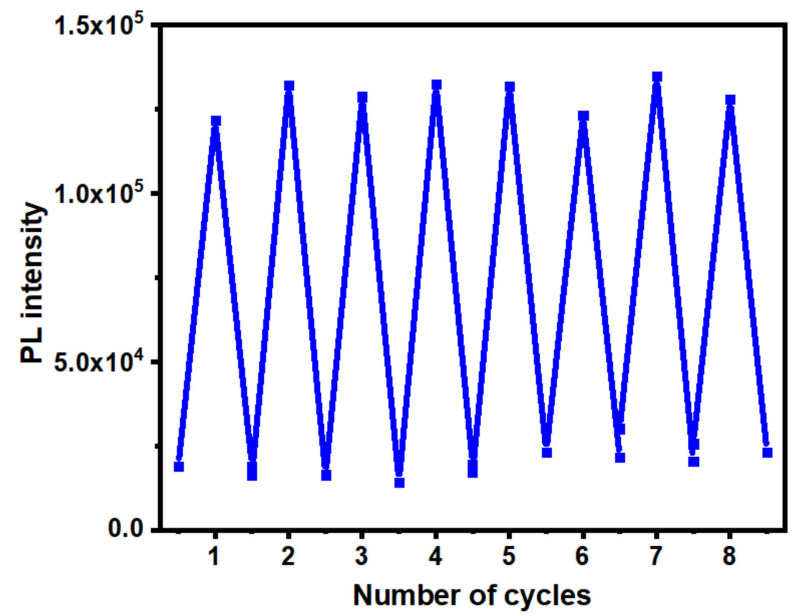

Figure 6. Recyclability study of M1 with DCM vapors. The emission of M1 after being exposed to $\mathrm{DCM}$ vapor returns to its original intensity by heating it at $80^{\circ} \mathrm{C}$ continuously for $30 \mathrm{~s}$.

The halogen bonding is well known where the halo atom (from DCM or chloroform) behaves as electron acceptor and interacts with the electron rich species [31-34]. In the present paper, the H-bonding was observed with chlorine and it was supported by Raman spectroscopy. A RAMAN spectroscopy experiment was studied to understand the mechanism for sensitive and selective sensing of DCM towards M1. The interaction of DCM with M1 is shown in the schematic representative structural model with labeled characteristic bonds to explain the observed Raman peak (Figure 7).

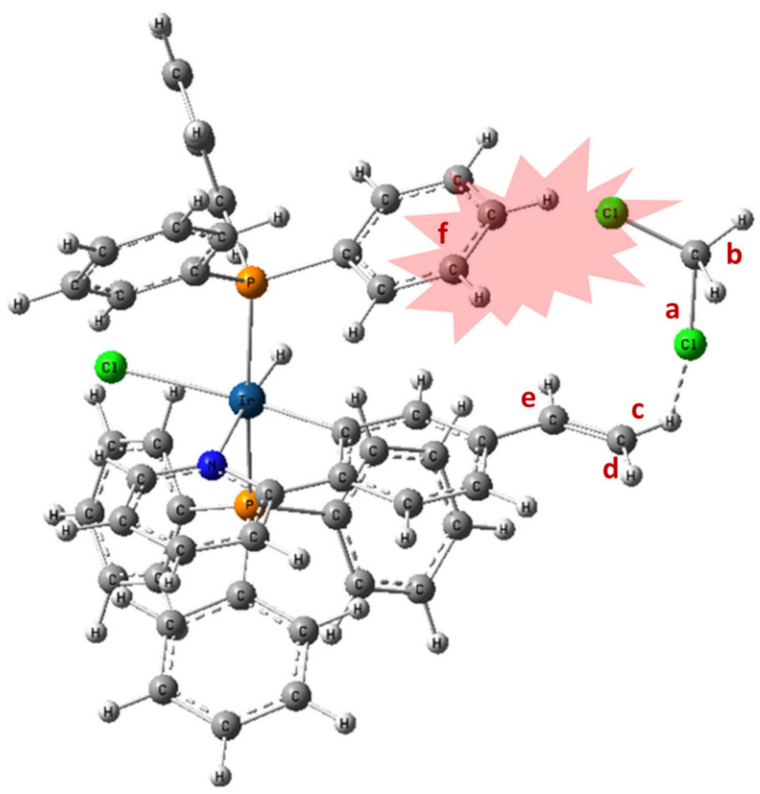

Figure 7. Schematic representative structural model of interaction of DCM with M1 labeling with characteristic bonds; (a) C-Cl and (b) C-H bonds of a bound DCM; (c-e) are the vinylic C-H bonds of $\mathrm{M} 1$; and (f) is the phenyl ring of triphenylphosphine $\left(\mathrm{PPh}_{3}\right)$. 
The RAMAN peaks for C-Cl and C-H symmetric stretching for a bare DCM molecule were reported at 713 and $2996 \mathrm{~cm}^{-1}$, respectively [35]. While treating M1 with DCM, some changes in original $\mathrm{C}-\mathrm{Cl}$ and $\mathrm{C}-\mathrm{H}$ stretching peaks were observed. The symmetric stretching of $\mathrm{C}-\mathrm{Cl}$ (a) is reduced to $699 \mathrm{~cm}^{-1}$ and symmetric stretching of $\mathrm{C}-\mathrm{H}(\mathrm{b})$ is lowered from $2996 \mathrm{~cm}^{-1}$ to $2982 \mathrm{~cm}^{-1}$ (Figures 8 and 9B and Table 1). The original Raman peak for the case of C-H (c) in vinylic substituent of M1 in the complex is also changed (after treatment with DCM). The bending peak for $\mathrm{C}-\mathrm{H}(\mathrm{c})$ of substituted vinylic carbon $\left(=\mathrm{CH}_{2}\right)$, which is trans to ligand L1 of M1 (Figure 7) originally observed at $1025 \mathrm{~cm}^{-1}$ for M1, is reduced to $1022 \mathrm{~cm}^{-1}$ (Figure 9A), with a broader and clearer observation of splitting (as compared to bare M1) (considered as monoalkyl vinyl) [36]. The other $\mathrm{C}-\mathrm{H}$ stretching of vinylic parts, such as cis $\mathrm{C}-\mathrm{H}(\mathrm{d})$, bending vibrations of vinylic carbon $\left(=\mathrm{CH}_{2}\right)$ and a stretching $\mathrm{C}-\mathrm{H}(\mathrm{e})$ of vinyl carbon $(-\mathrm{CH}=)$ observed at $644 \mathrm{~cm}^{-1}$ and $3057 \mathrm{~cm}^{-1}$, respectively, [29] and these original vibrational Raman peaks for these bonds remain unchanged as compared with the DCM treated M1 (Figures 8 and $9 \mathrm{~B}$ and Table 1).

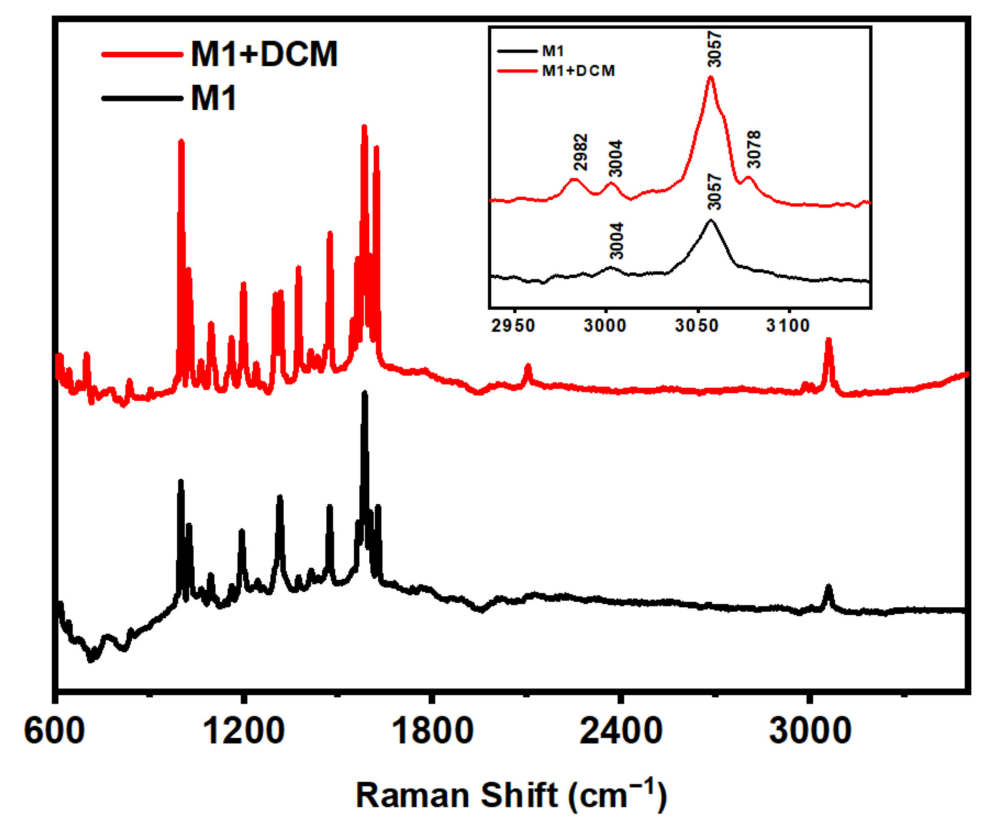

Figure 8. Raman spectra for solid M1 before and after DCM treatment (inset: enlarged view of several peaks).

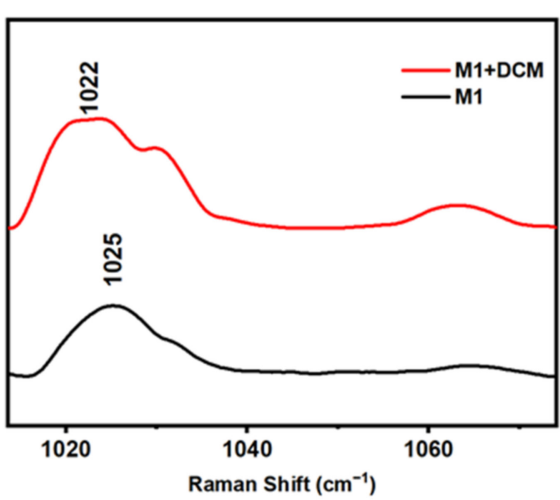

(A)

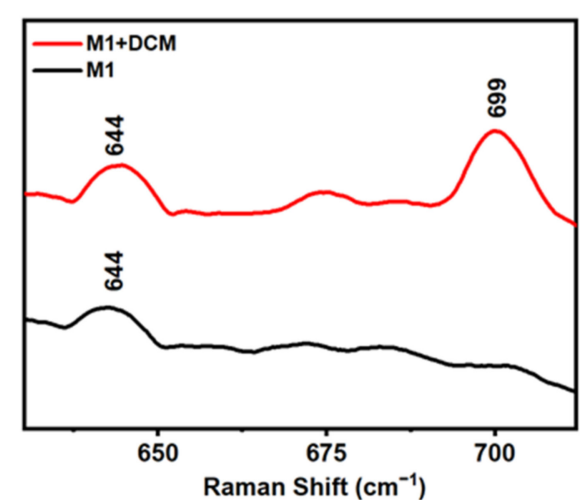

(B)

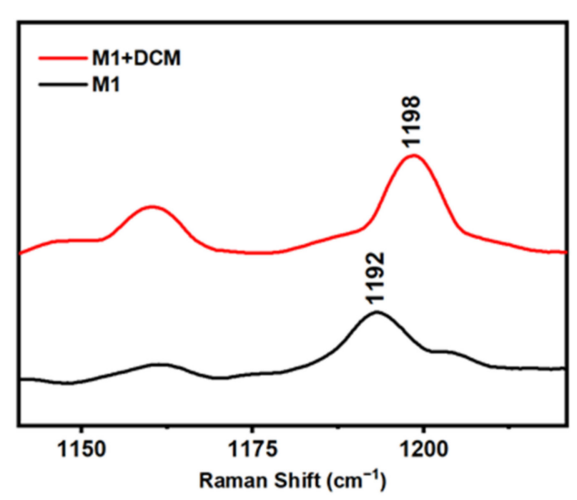

(C)

Figure 9. Enlarged views of RAMAN spectra (partwise): (A) The bending peak for $\mathrm{C}-\mathrm{H}(\mathrm{c})$ of vinyl $\left(=\mathrm{CH}_{2}\right)$, (B) the cis $\mathrm{C}-\mathrm{H}(\mathrm{d})$ bending vibrations of vinyl $\left(=\mathrm{CH}_{2}\right)$ and symmetric stretching $\mathrm{C}$ $\mathrm{Cl}(\mathrm{a})$ of treated DCM at $699 \mathrm{~cm}^{-1}$, (C) phenyl ring vibrations; (f) for mono-substituted phenyl of triphenylphosphine $\left(\mathrm{PPh}_{3}\right)$ increased from 1192 to $1198 \mathrm{~cm}^{-1}$. 
Table 1. Various vibrational modes for M1 and DCM treated M1.

\begin{tabular}{|c|c|c|c|c|}
\hline \multirow[b]{2}{*}{ Vibrational Modes } & \multicolumn{4}{|c|}{ Raman Shifts $\left(\mathrm{cm}^{-1}\right)$} \\
\hline & DCM only & $\begin{array}{l}\text { DCM (in } \\
\text { M1+DCM) }\end{array}$ & M1 only & $\begin{array}{c}\text { M1 (in } \\
\text { M1+DCM) }\end{array}$ \\
\hline C-Cl symmetric stretching (a) & 713 & 699 & - & - \\
\hline C-H symmetric stretching (b) & 2996 & 2982 & - & - \\
\hline $\mathrm{C}-\mathrm{H}$ bending $(\mathrm{c})$ & - & - & 1025 & 1022 \\
\hline C-H bending (d) & - & - & 644 & 644 \\
\hline C-H stretching (e) & - & - & 3057 & 3057 \\
\hline $\begin{array}{l}\mathrm{C}-\mathrm{H} \text { antisymmetric stretching } \\
\text { of vinylic carbon }\left(=\mathrm{CH}_{2}\right)(\mathrm{c}, \mathrm{d})\end{array}$ & - & - & - & 3078 \\
\hline $\begin{array}{l}\mathrm{C}-\mathrm{H} \text { symmetric stretching of } \\
\text { vinylic carbon }\left(=\mathrm{CH}_{2}\right)(\mathrm{c}, \mathrm{d})\end{array}$ & - & - & 3004 & 3004 \\
\hline $\begin{array}{l}\text { Phenyl ring vibrations of } \\
\text { triphenylphosphine }\left(\mathrm{PPh}_{3}\right)(\mathrm{f})\end{array}$ & - & - & 1192 & 1198 \\
\hline
\end{tabular}

Moreover, the asymmetrical stretching peak corresponding to $\mathrm{C}-\mathrm{H}(\mathrm{c}, \mathrm{d})$ of vinylic carbon $\left(=\mathrm{CH}_{2}\right)$ of M1 is prominently evolved at $3078 \mathrm{~cm}^{-1}$ for the case of DCM treated M1 (the same peak was not observed for the bare M1) (Figure 8). However, the original symmetrical stretching peak for $\mathrm{C}-\mathrm{H}(\mathrm{c}, \mathrm{d})$ of vinylic carbon $\left(=\mathrm{CH}_{2}\right)$ of $\mathrm{M} 1$ observed at $3004 \mathrm{~cm}^{-1}$ becomes stronger, relative to the M1 treated with DCM (Figure 8). We have carried out the Raman analysis for the M1 with dibromomethane (DBM) (Figures S13 and S14, and Table S1 +ESI) and diiodomethane (DIM) (Figures S15 and S16, and Table S2 tESI). A change in Raman shift for M1 with DBM (similar to DCM) was observed, while no change in Raman shift was observed with DIM. After studying the Raman peaks, all the changes are centered on $\mathrm{C}-\mathrm{H}$ (c) of vinylic substituent of $\mathrm{M} 1$ and the $\mathrm{C}-\mathrm{Cl}$ of DCM. This signifies that the $\mathrm{C}-\mathrm{Cl}$ (a) of DCM loosely interacts with the trans $\mathrm{C}-\mathrm{H}$ (c) of vinyl $\left(=\mathrm{CH}_{2}\right)$ of M1, while exposing to DCM and supporting the proposed model.

Furthermore, phenyl ring vibrations (f) for a phenyl of triphenylphosphine $\left(\mathrm{PPh}_{3}\right)$ increased from 1192 to $1198 \mathrm{~cm}^{-1}$ (Figures 7 and 9C and Table 1) [37]. The fact can be rationalized with the lowering of the vibrations of the phenyl ring because of the restriction imposed by the DCM (Figures 7 and 9 C). As a result, the turn-on emission was observed $[25,38]$. This turn-on emission further supported a low-temperature experiment (Figure S17, +ESI). The non-emissive powdered M1 shows the same yellow emission at low temperature where turn-on luminescence will be observed by restricted intramolecular motion [39]. On studying the FESEM image, M1 shows an inter-linked nano-rod and non-porous microstructure. An FESEM image of DCM treated M1 (after treating with DCM) results in a totally different morphology, i.e., a porous with a honey-comb type of structure (Figure S18, +ESI). The restriction on the movement of some part of M1 (vinyl and $\mathrm{PPh}_{3}$ units) results from the DCM molecule's interactive force, which may lead to the observed microporous nature.

Thermogravimetric analysis (TGA) gives an understanding of the thermal stability of a sample by giving a weight loss for M1, and DCM treated M1 (Figure S19, +ESI). The synthesized M1 is thermally stable up to $250{ }^{\circ} \mathrm{C}$. The sample holder containing powdered M1 was exposed to DCM and kept in open air for 5 min to evaporate excess DCM. The DCM treated M1 analyzed by TGA was observed to have around 13\% weight loss at up to $80^{\circ} \mathrm{C}$. It supports the presence of DCM, which is loosely bound to M1.

\section{Materials and Methods}

\subsection{Materials}

The starting materials 4-vinylphenylboronic acid, tetrakis(triphenylphosphine)palladium (0), iridium(III) chloride hydrate were purchased from TCI chemicals (Tokyo, Japan). 2 bromopyridine was purchased from Alfa Aesar company (Thermo Fisher Scientific, Kandel, Germany). Potassium carbonate $\left(\mathrm{K}_{2} \mathrm{CO}_{3}\right)$, Sodium carbonate $\left(\mathrm{Na}_{2} \mathrm{CO}_{3}\right)$, triphenylphosphine 
$\left(\mathrm{PPh}_{3}\right)$, 2-ethoxyethanol, and the UV grade solvents (tetrahydrofuran (THF), hexane, toluene, ethanol, and polyethylene glycol (PEG) were procured from Spectrochem (Mumbai, India), Merck company (Darmstadt, Germany).

\subsection{Instrumentation}

${ }^{1} \mathrm{H}-\mathrm{NMR},{ }^{13} \mathrm{C}-\mathrm{NMR}$ and ${ }^{31} \mathrm{P}-\mathrm{NMR}$ spectra were recorded using a $400 \mathrm{MHz}$ Brucker NMR spectroscope (Billerica, MA, USA). High-resolution mass spectra were recorded on Agilent 6545 Q-TOF LC/MS. UV-VIS absorption spectra were recorded using a Shimadzu Spectrophotometer (model UV-1800 and 2550, Kyoto, Japan). The Steady-state photoluminescence (PL) spectra were recorded on a Horiba Jobin Yvon Spectrofluorometer (FluoroMax-4) and Horiba 'FluoroLog-3' Spectrofluorimeter (Tokyo, Japan). The variation in particle size in aggregated state was recorded by dynamic light scattering (DLS) experiment, using Anton Paar Litesizer 500 at $25^{\circ} \mathrm{C}$ temperature. Raman analysis studied by HORIBASCI Raman instrument (model no. LabRAM HR EVO) using excitation lasers with $633 \mathrm{~nm}$ wavelength. Microscope version, XT Platform version, XT UI version, Modal"APREO S" FE-SEM was used to investigate the morphology of the synthesized M1 sample. Thermogravimetric analysis (TGA) was performed by TGA-50, SHIMADZU equipment at $10^{\circ} \mathrm{C} / \mathrm{min}$, under a nitrogen atmosphere.

\subsection{Experimental Procedure}

\subsubsection{Synthesis of Ligand L1}

In a $250 \mathrm{~mL}$ round bottom flask, a mixture of 4-vinylphenylboronic acid $(1.31 \mathrm{~g}$, $8.85 \mathrm{mmol}), \mathrm{K}_{2} \mathrm{CO}_{3}(3.29 \mathrm{~g}, 10.12 \mathrm{mmol})$, toluene: ethanol (10:1, $\left.22 \mathrm{~mL}\right), 2$-bromopyridine $(1 \mathrm{~g}, 6.32 \mathrm{mmol})$ stirred under $\mathrm{N}_{2}$ gas for $5 \mathrm{~min}$. The catalyst tetrakis (triphenylphosphine)palladium(0) added and refluxed for $5 \mathrm{~h}$ at $100{ }^{\circ} \mathrm{C}$ temperature. Then, it was cooled to room temperature. The reaction was quenched with the addition of water and washed with brine solution, then extracted with ethyl acetate finally dried with anhydrous $\mathrm{Na}_{2} \mathrm{SO}_{4}$, (filtration over celite to remove insoluble palladium catalyst residues). The crude product was purified by column chromatography, with Hexane: Ethyl acetate (95:5) as eluent. A colorless oil isolated as the desired vinyl substituted phenylpyridine ligand (yield, 83.8\%).

${ }^{1} \mathrm{H}-\mathrm{NMR}(400 \mathrm{MHz}$, Chloroform- $d$ ) $\delta 8.72(\mathrm{~d}, J=4.6 \mathrm{~Hz}, 1 \mathrm{H}), 8.00(\mathrm{~d}, J=8.4 \mathrm{~Hz}$, 2H), 7.81-7.72 (m, 2H), $7.55(\mathrm{~d}, J=8.3 \mathrm{~Hz}, 2 \mathrm{H}), 7.25(\mathrm{ddd}, J=6.0,4.9,2.6 \mathrm{~Hz}, 1 \mathrm{H}), 6.80$ $(\mathrm{dd}, J=17.6,10.9 \mathrm{~Hz}, 1 \mathrm{H}), 5.85(\mathrm{dd}, J=17.6,0.9 \mathrm{~Hz}, 1 \mathrm{H}), 5.33(\mathrm{dd}, J=10.9,0.9 \mathrm{~Hz}, 1 \mathrm{H})$ (Figure S1). ${ }^{13} \mathrm{C}-\mathrm{NMR}(101 \mathrm{MHz}$, Chloroform-d) $\delta$ 157.01, 149.68, 138.70, 138.20, 136.74, $136.40,127.04,126.62,122.09,120.42,114.49$ (Figure S2).

\subsubsection{Synthesis of Iridium Complex M1}

In a $50 \mathrm{~mL}$ round bottom flask, a mixture of iridium(III) chloride hydrate $(0.216 \mathrm{~g}$, $1.19 \mathrm{mmol})$, triphenylphosphine $(0.650 \mathrm{~g}, 2047 \mathrm{mmol})$ and $4 \mathrm{~mL}$ of 2-ethoxyethanol solvent, stirred for $3 \mathrm{~h}$ at $125{ }^{\circ} \mathrm{C}$ temperature. While stirring the mixture for $3 \mathrm{~h}$, it turned into yellow colored liquid. Then, L1 $(0.216 \mathrm{~g}, 1.19 \mathrm{mmol})$ and $\mathrm{Na}_{2} \mathrm{CO}_{3}(0.432 \mathrm{~g}, 4.07 \mathrm{mmol})$ added and refluxed for $3 \mathrm{~h}$ at $125^{\circ} \mathrm{C}$ temperature under the nitrogen gas. The reaction was quenched with the addition of water, then extracted with ethyl acetate finally dried with anhydrous $\mathrm{Na}_{2} \mathrm{SO}_{4}$. The crude product was purified by column chromatography, with Hexane: Ethyl acetate (80:20) as eluent. Yellow colored solid isolated as desired M1 with $40 \%$ yield. The product was characterized by ${ }^{1} \mathrm{H},{ }^{13} \mathrm{C}$ and ${ }^{31} \mathrm{P}-\mathrm{NMR}$ spectra.

${ }^{1} \mathrm{H}-\mathrm{NMR}(400 \mathrm{MHz}$, Chloroform- $d) \delta 8.97(\mathrm{~d}, J=5.6 \mathrm{~Hz}, 1 \mathrm{H}), 7.42-7.36(\mathrm{~m}, 15 \mathrm{H})$, $7.18-7.15(\mathrm{~m}, 7 \mathrm{H}), 7.12(\mathrm{dt}, J=7.4,1.2 \mathrm{~Hz}, 11 \mathrm{H}), 6.65(\mathrm{dt}, J=7.1,1.6 \mathrm{~Hz}, 2 \mathrm{H}), 6.29(\mathrm{~s}, 1 \mathrm{H})$, $5.95(\mathrm{dd}, J=17.5,10.8 \mathrm{~Hz}, 1 \mathrm{H}), 5.13(\mathrm{dd}, J=17.5,1.4 \mathrm{~Hz}, 1 \mathrm{H}), 4.85(\mathrm{dd}, J=10.8,1.4 \mathrm{~Hz}, 1 \mathrm{H})$, -16.82 (s, 1H) (Figure S3).

${ }^{13}$ C-NMR (101 MHz, Chloroform-d) $\delta$ 149.78, 141.77, 137.61, 135.29, 134.14, 134.07, 134.02, 133.96, 131.94, 131.67, 131.41, 129.10, 128.99, 127.21, 127.16, 127.12, 122.30, 120.35, 117.61, 117.19, 112.30 (Figure 4).

${ }^{31}$ P-NMR (162 MHz, Chloroform-d) $\delta 9.01$ (Figure S5). 
ESI-HRMS calculated: [M-Cl] ${ }^{+}: m / z=898.21$; found: [M-Cl] ${ }^{+}: m / z=898.23$ (Figure S6).

\section{Conclusions}

In this work, a new AIE active mono-cyclometalated Ir(III) complex M1 synthesized by a simple and straightforward reaction pathway which shows vapochromic dichloromethane (DCM) detection. The M1 exhibits a bright turn-on emission in the presence of DCM vapor $\left(\lambda_{\mathrm{emi}}, 530 \mathrm{~nm}\right)$. The mechanism of DCM sensing was explored by Raman spectroscopy. The notable achievements are the selective and sensitive detection of DCM and the reusability of probe M1. The observed DCM detection limit is $4.9 \mathrm{ppm}$ in the vapor-phase with pristine M1. To the best of our knowledge, the observed LOD for the detection of DCM vapor with pristine probe showed the best result. Moreover, such a technique for the detection of DCM would be cost-effective and shows potentiality for commercialization. The work should inspire the development of convenient routes for the development of new materials to detect VOCs from the workplace in industries/laboratories.

Supplementary Materials: The following are available online at. Figures $\mathrm{S} 1$ and $\mathrm{S} 2:{ }^{1} \mathrm{H},{ }^{13} \mathrm{C}-\mathrm{NMR}$ spectrum of L1; Figures S3-S5: ${ }^{1} \mathrm{H},{ }^{13} \mathrm{C},{ }^{31} \mathrm{P}-\mathrm{NMR}$ spectrums of M1; Figure S6: Mass spectrum of compound M1; Figure S7: DLS particle size distribution plot of M1; Figure S8: AIE study of M1 in tetrahydrofuran (THF): polyethylene glycol (PEG) mixtures; Figure S9: The optimized geometry of M1; Figure S10: Emission plot for powdered M1 with DCM and DBM; Figure S11: Photograph of DCM vapor sensing setup; Figure S12: Calculation of limit of detection for M1 in vapor phase; Figures S13 and S14: Schematic representation for the structural model of interaction of DBM with M1 and respective Raman plot; Table S1: Various vibrational modes for M1 and DBM treated M1; Figure S15 and S16: Schematic representative structural model of interaction of DIM with M1 and respective Raman plot; Table S2: Various vibrational modes for M1 and DBM treated M1; Figure S17: (a) Photograph of low temperature study for M1; Figure S18: FESEM images for before and after addition of DCM to powdered M1; Figure S19: TGA plot of M1 for before and after DCM treated.

Author Contributions: Investigation, P.C.R.; methodology, P.C.R.; supervision, I.R.L.; writingoriginal draft, V.K.; writing - review and editing, I.R.L. All authors have read and agreed to the published version of the manuscript.

Funding: This research received no external funding.

Institutional Review Board Statement: Not applicable.

Informed Consent Statement: Not applicable.

Data Availability Statement: Data supporting the findings of this study are available within the article and Supplementary Materials.

Acknowledgments: The authors gratefully acknowledge Birla Institute of Technology and Science (BITS) Pilani, Pilani campus, Rajasthan (India) for the fellowship to P.C.R., we acknowledge gratefully the support from the Department of Biotechnology (DBT), GOVERNMENT OF INDIA (project number: BT/PR33133/MED/32/704/2019) for chemical purchase. The 'UGC-sponsored Special Assistance Programme (F.540/14/DRS/2007, SAP-I)' and DST-FIST (SR/ FST/CSI-270/2015) for the HRMS facility in the chemistry department, BITS Pilani are acknowledged for instrumental support.

Conflicts of Interest: The authors declare no conflict of interest.

Sample Availability: Samples of the compounds are not available from the authors.

\section{References}

1. Li, H.-Y.; Zhao, S.-N.; Zang, S.-Q.; Li, J. Functional metal-organic frameworks as effective sensors of gases and volatile compounds. Chem. Soc. Rev. 2020, 49, 6364-6401. [CrossRef] [PubMed]

2. Dichloromethane. IARC Monographs on the Evaluation of Carcinogenic Risks to Humans; IARC: Lyon, France, 1999; Volume 71, Pt 1, pp. 251-315.

3. Morrison, R.D.; Murphy, B.L.; Doherty, R.E. 12-Chlorinated Solvents. In Environmental Forensics; Morrison, R.D., Murphy, B.L., Eds.; Academic Press: Burlington, VT, USA, 1964; pp. 259-277. [CrossRef]

4. Vidal, S. Safety First: A Recent Case of a Dichloromethane Injection Injury. ACS Cent. Sci. 2020, 6, 83-86. [CrossRef] 
5. MacMillan, D.S.; Murray, J.; Sneddon, H.F.; Jamieson, C.; Watson, A.J.B. Replacement of dichloromethane within chromatographic purification: A guide to alternative solvents. Green Chem. 2012, 14, 3016-3019. [CrossRef]

6. Han, J.; Yoon, S.M. Dichloromethane Detection Based on Near-Infrared Absorptive Sensing. IEEE J. Sel. Top. Quantum Electron. 2012, 18, 1547-1552. [CrossRef]

7. Sakai, T.; Morita, Y.; Wakui, C. Biological monitoring of workers exposed to dichloromethane, using head-space gas chromatography. J. Chromatogr. B 2002, 778, 245-250. [CrossRef]

8. Poli, D.; Manini, P.; Andreoli, R.; Franchini, I.; Mutti, A. Determination of dichloromethane, trichloroethylene and perchloroethylene in urine samples by headspace solid phase microextraction gas chromatography-mass spectrometry. J. Chromatogr. B 2005, 820, 95-102. [CrossRef]

9. Lopes, N.; Hawkins, S.A.; Jegier, P.; Menn, F.-M.; Sayler, G.S.; Ripp, S. Detection of dichloromethane with a bioluminescent (lux) bacterial bioreporter. J. Ind. Microbiol. Biotechnol. 2012, 39, 45-53. [CrossRef] [PubMed]

10. Jiang, Y.; Ma, J.; Lv, J.; Ma, H.; Xia, H.; Wang, J.; Yang, C.; Xue, M.; Li, G.; Zhu, N. Facile Wearable Vapor/Liquid Amphibious Methanol Sensor. ACS Sens. 2019, 4, 152-160. [CrossRef] [PubMed]

11. Husain, A. Electrical conductivity based ammonia, methanol and acetone vapour sensing studies on newly synthesized polythiophene/molybdenum oxide nanocomposite. J. Sci. Adv. Mater. Devices 2021. [CrossRef]

12. Zhang, H.; Niu, X.; Zhu, S.; Tian, M.; Liu, W. Synthesis, characterization, and enhanced aggregation-induced emission of oligomer methylacryloyl tetraphenylethylene and volatile organic compounds detection. J. Appl. Polym. Sci. 2021, 51699. [CrossRef]

13. Duan, Y.; Liu, Y.; Han, H.; Zhang, X.; Zhang, M.; Liao, Y.; Han, T. A donor- $\pi$-acceptor aggregation-induced emission compound serving as a portable fluorescent sensor for detection and differentiation of methanol and ethanol in the gas phase. Spectrochim. Acta Part A Mol. Biomol. Spectrosc. 2021, 252, 119515. [CrossRef]

14. Liu, Y.; Fan, Y.; Hou, C.; Du, W.; Zhang, D.; Liu, Y.; Xu, J.; Bai, Y.-L. Highly Selective Chloromethanes Detection Based on Quartz Crystal Microbalance Gas Sensors with Ba-MOFs. Inorg. Chem. 2021, 60, 16370-16377. [CrossRef]

15. Liu, H.; Bai, Q.; Yao, L.; Zhang, H.; Xu, H.; Zhang, S.; Li, W.; Gao, Y.; Li, J.; Lu, P.; et al. Highly efficient near ultraviolet organic light-emitting diode based on a meta-linked donor-acceptor molecule. Chem. Sci. 2015, 6, 3797-3804. [CrossRef] [PubMed]

16. Kramarenko, M.; Ferreira, C.G.; Martínez-Denegri, G.; Sansierra, C.; Toudert, J.; Martorell, J. Relation between Fluorescence Quantum Yield and Open-Circuit Voltage in Complete Perovskite Solar Cells. Sol. RRL 2020, 4, 1900554. [CrossRef]

17. Alam, P.; Leung, N.L.C.; Zhang, J.; Kwok, R.T.K.; Lam, J.W.Y.; Tang, B.Z. AIE-based luminescence probes for metal ion detection Coord. Chem. Rev. 2021, 429, 213693. [CrossRef]

18. He, X.; Yang, Y.; Guo, Y.; Lu, S.; Du, Y.; Li, J.-J.; Zhang, X.; Leung, N.L.C.; Zhao, Z.; Niu, G.; et al. Phage-Guided Targeting, Discriminative Imaging, and Synergistic Killing of Bacteria by AIE Bioconjugates. J. Am. Chem. Soc. 2020, 142, 3959-3969. [CrossRef] [PubMed]

19. Alam, P.; Kaur, G.; Chakraborty, S.; Roy Choudhury, A.; Laskar, I.R. "Aggregation induced phosphorescence" active "rollover" iridium(iii) complex as a multi-stimuli-responsive luminescence material. Dalton Trans. 2015, 44, 6581-6592. [CrossRef]

20. Luo, J.; Xie, Z.; Lam, J.W.Y.; Cheng, L.; Chen, H.; Qiu, C.; Kwok, H.S.; Zhan, X.; Liu, Y.; Zhu, D.; et al. Aggregation-induced emission of 1-methyl-1,2,3,4,5-pentaphenylsilole. Chem. Commun. 2001, 1740-1741. [CrossRef] [PubMed]

21. Fageria, L.; Pareek, V.; Dilip, R.V.; Bhargava, A.; Pasha, S.S.; Laskar, I.R.; Saini, H.; Dash, S.; Chowdhury, R.; Panwar, J Biosynthesized Protein-Capped Silver Nanoparticles Induce ROS-Dependent Proapoptotic Signals and Prosurvival Autophagy in Cancer Cells. ACS Omega 2017, 2, 1489-1504. [CrossRef]

22. Kim, H.; Choi, S.-K.; Ahn, J.; Yu, H.; Min, K.; Hong, C.; Shin, I.-S.; Lee, S.; Lee, H.; Im, H.; et al. Kaleidoscopic fluorescent arrays for machine-learning-based point-of-care chemical sensing. Sens. Actuators B: Chem. 2021, 329, 129248. [CrossRef]

23. Hu, J.; Liu, Y.; Zhang, X.; Han, H.; Li, Z.; Han, T. Fabricating a mechanochromic AIE luminogen into a wearable sensor for volatile organic compound (VOC) detection. Dye. Pigment. 2021, 192, 109393. [CrossRef]

24. Mo, K.-Q.; Ma, X.-F.; Wang, H.-L.; Zhu, Z.-H.; Liu, Y.-C.; Zou, H.-H.; Liang, F.-P. Tracking the Multistep Formation of Ln(III) Complexes with in situ Schiff Base Exchange Reaction and its Highly Selective Sensing of Dichloromethane. Sci. Rep. 2019, 9, 12231. [CrossRef] [PubMed]

25. Liu, C.-Y.; Chen, X.-R.; Chen, H.-X.; Niu, Z.; Hirao, H.; Braunstein, P.; Lang, J.-P. Ultrafast Luminescent Light-Up Guest Detection Based on the Lock of the Host Molecular Vibration. J. Am. Chem. Soc. 2020, 142, 6690-6697. [CrossRef]

26. Zhang, K.; Chen, T.-T.; Shen, Y.-J.; Yang, Z.-R.; Huang, Y.; Zhang, S.; Xue, J.; Li, B. An N-linked disalicylaldehyde together with its caesium ion and dichloromethane sensing performances: 'dual key \& lock' LMCT-enhanced fluorescence strategy. Analyst 2020, 145, 5826-5835. [CrossRef]

27. Wang, H.; Zhan, S.; Wu, X.; Wu, L.; Liu, Y. Nanoporous fluorescent sensor based on upconversion nanoparticles for the detection of dichloromethane with high sensitivity. RSC Adv. 2021, 11, 565-571. [CrossRef]

28. Alam, P.; Kaur, G.; Kachwal, V.; Gupta, A.; Roy Choudhury, A.; Laskar, I.R. Highly sensitive explosive sensing by "aggregation induced phosphorescence" active cyclometalated iridium(iii) complexes. J. Mater. Chem. C 2015, 3, 5450-5456. [CrossRef]

29. García-Sánchez, F.; Romero-Martínez, A.; Trejo, A. Vapour pressure, critical temperature, and critical pressure of dichloromethane. J. Chem. Thermodyn. 1989, 21, 823-826. [CrossRef]

30. Schlosser Paul, M.; Bale Ambuja, S.; Gibbons Catherine, F.; Wilkins, A.; Cooper Glinda, S. Human Health Effects of Dichloromethane: Key Findings and Scientific Issues. Environ. Health Perspect. 2015, 123, 114-119. [CrossRef] 
31. Berger, G.; Soubhye, J.; Wintjens, R.; Robeyns, K.; Meyer, F. Crystal packing and theoretical analysis of halogen- and hydrogenbonded hydrazones from pharmaceuticals. Evidence of type I and II halogen bonds in extended chains of di \-chloro $\backslash$-methane. Acta Crystallogr. Sect. B 2018, 74, 618-627. [CrossRef]

32. Ivanov, D.M.; Kinzhalov, M.A.; Novikov, A.S.; Ananyev, I.V.; Romanova, A.A.; Boyarskiy, V.P.; Haukka, M.; Kukushkin, V.Y. $\mathrm{H} 2 \mathrm{C}(\mathrm{X})-\mathrm{X} \cdots \mathrm{X}-(\mathrm{X}=\mathrm{Cl}, \mathrm{Br})$ Halogen Bonding of Dihalomethanes. Cryst. Growth Des. 2017, 17, 1353-1362. [CrossRef]

33. Cavallo, G.; Metrangolo, P.; Milani, R.; Pilati, T.; Priimagi, A.; Resnati, G.; Terraneo, G. The Halogen Bond. Chem. Rev. 2016, 116, 2478-2601. [CrossRef]

34. Berger, G.; Frangville, P.; Meyer, F. Halogen bonding for molecular recognition: New developments in materials and biological sciences. Chem. Commun. 2020, 56, 4970-4981. [CrossRef] [PubMed]

35. Kurzydłowski, D.; Chumak, T.; Rogoża, J. Phase Stability of Chloroform and Dichloromethane at High Pressure. Crystals 2020, 10, 920. [CrossRef]

36. Lin-Vien, D.; Colthup, N.B.; Fateley, W.G.; Grasselli, J.G. CHAPTER 6-Alkenes. In The Handbook of Infrared and Raman Characteristic Frequencies of Organic Molecules; Lin-Vien, D., Colthup, N.B., Fateley, W.G., Grasselli, J.G., Eds.; Academic Press: San Diego, CA, USA, 1991; pp. 73-94. [CrossRef]

37. Garcia, M.A.S.; Ibrahim, M.; Costa, J.C.S.; Corio, P.; Gusevskaya, E.V.; dos Santos, E.N.; Philippot, K.; Rossi, L.M. Study of the influence of PPh3 used as capping ligand or as reaction modifier for hydroformylation reaction involving Rh NPs as precatalyst. Appl. Catal. A: Gen. 2017, 548, 136-142. [CrossRef]

38. APPENDIX 3-A Summary of Characteristic Raman and Infrared Frequencies. In The Handbook of Infrared and Raman Characteristic Frequencies of Organic Molecules; Lin-Vien, D.; Colthup, N.B.; Fateley, W.G.; Grasselli, J.G. (Eds.) Academic Press: San Diego, CA, USA, 1991; pp. 477-490. [CrossRef]

39. Mei, J.; Hong, Y.; Lam, J.W.Y.; Qin, A.; Tang, Y.; Tang, B.Z. Aggregation-Induced Emission: The Whole Is More Brilliant than the Parts. Adv. Mater. 2014, 26, 5429-5479. [CrossRef] [PubMed] 